\title{
BIOMONITORING OF ATMOSPHERIC AEROSOL WITH THE USE OF Apis mellifera AND Pleurozium schreberi
}

\author{
BIOMONITORING AEROZOLU ATMOSFERYCZNEGO \\ Z WYKORZYSTANIEM Apis mellifera I Pleurozium schreberi
}

\begin{abstract}
The aim of the carried out research was to assess atmospheric aerosol pollution levels in the area of three apiaries located in the Opole Province and to analyse heavy metals pollution in bee honey and western honey bees. Pleurozium schreberi moss was used in analysing atmospheric aerosol pollution with the active biomonitoring method, whereas heavy metals levels were determined with flame atomic absorption spectrometry method (F-AAS). Relative Accumulation Factors $(R A F)$ were used in determining increases of analytes concentrations in the moss samples. As a result of the carried out study, the following conclusions have been reached: mosses are good bioindicators of environment pollution thanks to their sorption qualities, similarly to honey bees, which are a bioindicator of environment pollution. According to the Commission Regulation of European Union of 2015 regarding the maximum levels of lead in certain foods (honey), it should not exceed $0.1 \mathrm{mg} / \mathrm{kg}$. On the basis of the carried out study it can be stated that the concentration of this analyte in the analysed honey was below the limit of quantification of the applied analytical method.
\end{abstract}

Keywords: Pleurozium schreberi mosses, honey, bees, heavy metals, biomonitoring

\section{Introduction}

Western honey bee (Apis mellifera) has been used as a biomonitor in assessment of environment quality in the field and urban studies since 1935. It reacts quickly to various external factors, including changes of atmospheric air pollution (e.g. with heavy metals), which allows to determine the equilibrium between the health condition of humans and their status and life quality [1]. It is an important tool in ecotoxicology for assessing soil, water and air pollution with, among others, heavy metals, radioactive isotopes and pesticides [2]. The pollution accumulated in a bee's organism may indicate the level of environment pollution [3]. As pollinators and collectors of nectar and pollen, they play an important role in maintaining biodiversity and productivity of ecosystems. The form a natural resource by making various products: honey, pollen, wax, propolis and royal jelly. However, due to the ever increasing various environment pollution, the number of bees in Europe has considerably decreased in Europe by $25 \%$ since 1985 [4].

\footnotetext{
${ }^{1}$ Institute of Environmental Engineering and Biotechnology, University of Opole, ul. kard. B. Kominka 6, 45-032 Opole, Poland, phone +48 7740160 42, e-mail: mrajfur@ o2.pl, swislowskip@gmail.com

*Corresponding author: mrajfur@o2.pl
} 
Pollution of bees and bee products can be divided into two groups: environmental and beekeeping related. Beekeeping practices are an equally dangerous source of pollution of bee products as anthropogenic sources. The most important pollutants are the substances used by beekeepers to fight bee pests. Ecological beekeeping is an alternative method of bee pests fighting, by using minimum quantities of chemical substances. This, in turn, guarantees purity and safety of bee products, free from toxic chemical compounds [5].

If bee feed contains high quantities of heavy metals, their cell defence reactions can be impaired [6]. Study results confirm that various environmental conditions (pollution) influence productivity of colonies: honey yield, foraging behaviours, a colony survival, quality and quantity of products; additionally, these conditions considerably influence metabolic and physiological processes in bees [7]. In consequence of pollution transfer process, occurring between soil, plants, water and air, it also accumulates in bee hives. In consequence, pollution is transferred to royal jelly and, as it is fed to all larvae in the bee family - the presence of heavy metals directly influences all the colony members [8]. Many honey bees, which come into a direct contact with pollution, will not be strong enough to return to their hive and will die during flight. The number of dead bees in front of a hive (in the case of pesticide pollution) is the most important variable and indication of the environment condition. In general, heavy metals themselves do not cause deaths of honey bees, however, they may settle on bees' hairy bodies and be carried into a hive together with pollen $[9,10]$.

Bee products include a number of substances, such as propolis, royal jelly or pollen, which are known for their medicinal properties and their biological activity was used already in ancient period. Moreover, bee products are regarded as a potential source of natural antioxidants. Studies have been carried out on the potential use of these products in treatment of illnesses in humans [11]. For example, bee pollen has a wide array of therapeutic qualities due to a high content of nutrients and bioactive compounds. Studies on a wider pharmacological use of this product have been under way [12, 13]. The main problems with the use of bee pollen in modern medicine regard its unstable composition as well as the fact that the pollen collected by bees may contain pollutants (heavy metals, pesticides, herbicides, mycotoxins, bacteria or even antibiotics) [14].

Due to the increasing environment pollution level, heavy metals (e.g. copper, zinc, cadmium, mercury [15]) can be determined also in honey [16]. Honey contains also iron, aluminium, magnesium, manganese, chlorine, calcium, potassium and sodium [17]. The content of minerals will largely depend on the flowers, from which pollen is collected, therefore geographical location is of key importance [18]. It is recommended to place hives in the areas free from intense traffic communication routes or industrial operations [19] (bees fly intensively within the radius of up to $3 \mathrm{~km}$ [5], therefore they cover the area of approximately $50 \mathrm{~km}^{2}$ [20], making up to 15 foraging flights per day [21]). Taking into consideration that the production of $1 \mathrm{~kg}$ of honey requires approximately 100000 foraging flights, it becomes obvious that the substrates collected by bees for the production may contain various concentrations of analytes [22]. Some European Authorities suggest introduction of maximum residue limit $(M R L)$ in honey for cadmium $(0.1 \mathrm{mg} / \mathrm{kg})$ and lead $(1.0 \mathrm{mg} / \mathrm{kg})$ [23]. Whereas no regulations considering maximum level $(M L)$ for polycyclic aromatic hydrocarbons PAH were introduced [4]. Honey may be an important source of vitamins, micro- and macroelements indispensable for human health [24], however, consumption of polluted honey is particularly harmful for infants, children and youth [25]. 
The objective of the carried out research was to asses heavy metals pollution level of the selected area in the Opole Province, with the use of honey bees and their product honey. The pollution level of atmospheric aerosol with the selected analytes was additionally assessed with the use of the moss-bag active biomonitoring method [26]. The possibility to apply alternative biomonitors, in order to determine the pollution level of the analysed environment with heavy metals, was analysed. Additionally, the possibility to consume honey from the study area was assessed, taking into consideration the pollution levels, which may occur in food products.

\section{Material and methods}

Pleurozium schreberi mosses collected in Bory Stobrawskie (Opole Province) were used in the research. The moss collected for the research was taken to the laboratory and cleaned from needles and other impurities.
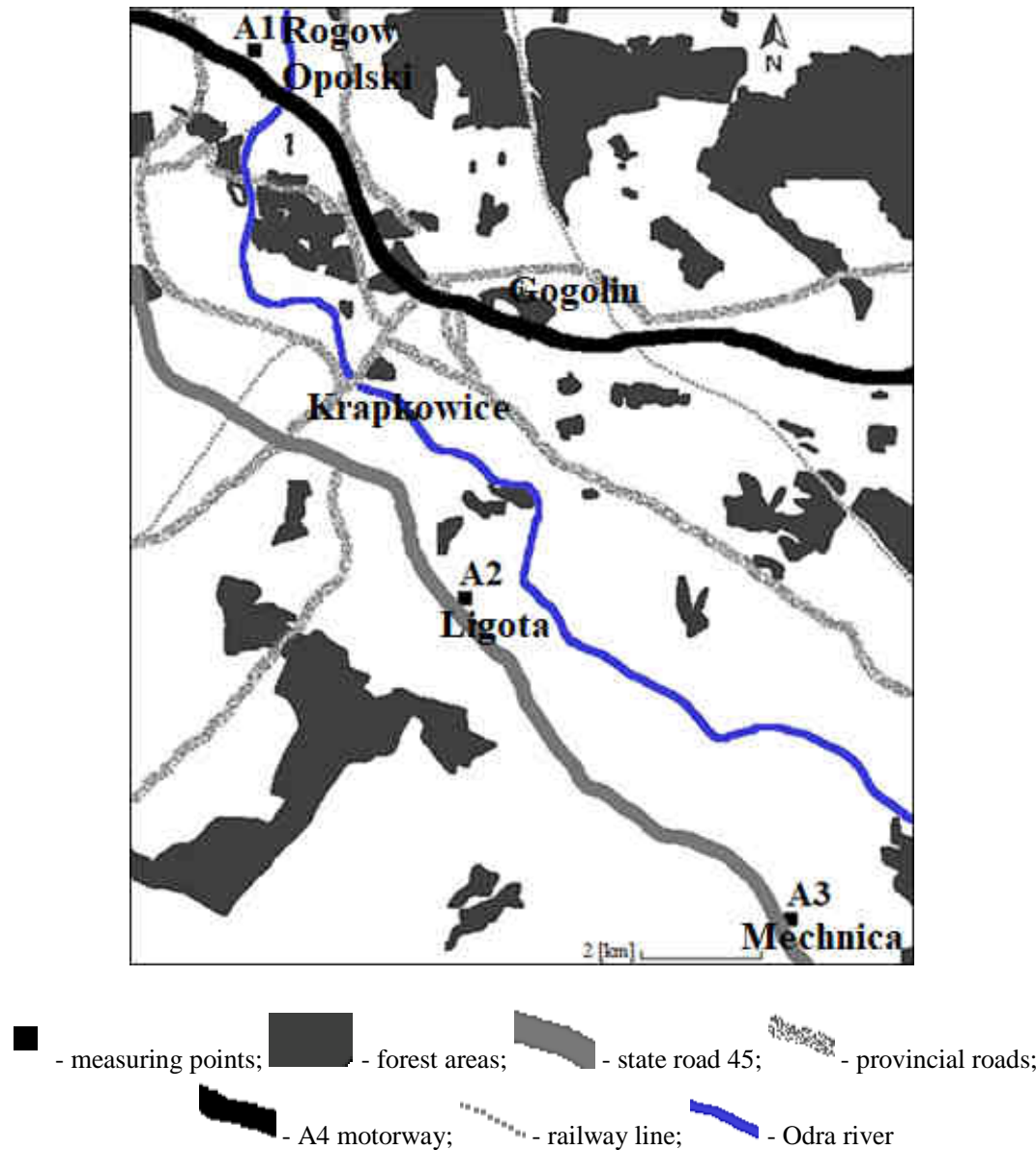

Fig. 1. Measuring points location 
The green part of the moss gametophyte was retained, rinsed three times with demineralised water and dried at room temperature for 48 hours until dry mass was obtained. Next, 9 bags were prepared, each with the mass of $2.00 \pm 0.01 \mathrm{~g}$. Such prepared moss samples were exposed at the height of approximately $1.5 \mathrm{~m}$ in three measuring points near every apiary. The moss exposition time was three months: July-September 2018.

The biomonitoring studies with the moss-bag method were carried out in the Opole Province, district Krapkowice. In each aviary located in: Rogow Opolski, Ligota and Mechnica, three measuring points in each were marked (Fig. 1).

Each moss sample after exposition with the mass of $0.400 \pm 0.001 \mathrm{~g}$ d.m. (d.m. - dry mass) were mineralised in the mixture of nitric acid(V) and hydrogen peroxide $\left(\mathrm{HNO}_{3} 65 \%: \mathrm{H}_{2} \mathrm{O}_{2} 37 \%=5: 3\right)$, using a Speedwave Four Berghof, DE microwave oven. Mineralisation process was carried out at temperature $180{ }^{\circ} \mathrm{C}$.

The honey samples from apiaries, in which biomonitoring studies were carried out, was dried in a drier at temperature of $50{ }^{\circ} \mathrm{C}$ for approximately 3 weeks and mineralised in the mixture of nitric acid(V) and hydrogen peroxide $\left(\mathrm{HNO}_{3} 65 \%: \mathrm{H}_{2} \mathrm{O}_{2} 37 \%=8: 2\right)$ in the same digester as moss.

Bees were collected from apiaries and dried to dry mass at temperature of $80{ }^{\circ} \mathrm{C}$ and next mineralised, according to the same procedure as moss samples.

Heavy metals ( $\mathrm{Mn}, \mathrm{Fe}, \mathrm{Ni}, \mathrm{Cu}, \mathrm{Zn}, \mathrm{Cd}$ and $\mathrm{Pb}$ ) were determined with the use of atomic absorption flame spectrometer (F-AAS) type iCE 3500 (series 3000) made by Thermo Scientific, USA.

\section{Quality control}

In Table 1, the instrumental detection limits $(I D L)$ and instrumental quantification limits $(I Q L)$ for the spectrometer, iCE 3500 are presented. The results were converted into $1 \mathrm{~kg}$ of sample. Calibration of the spectrometer was performer with a standard solution from ANALYTIKA Ltd. (CZ). The values of the highest concentrations of the models used for calibration $\left(7.5 \mathrm{mg} / \mathrm{dm}^{3}\right.$ for $\mathrm{Mn}, 10 \mathrm{mg} / \mathrm{dm}^{3}$ for $\mathrm{Fe}, 5 \mathrm{mg} / \mathrm{dm}^{3}$ for $\mathrm{Ni}, \mathrm{Cu}, \mathrm{Zn}, \mathrm{Pb}$, $2 \mathrm{mg} / \mathrm{dm}^{3}$ for $\mathrm{Cd}$ ) were approved as linear limits for signal dependence on concentration. Concentrations of metals were determined in solution after mineralisation and dilution to were filtered into volumetric flasks of $25 \mathrm{~cm}^{3}$.

The instrumental detection limits $(I D L)$ and instrumental quantification limits $(I Q L)$

Table 1 for the spectrometer iCE $3500\left[\mathrm{mg} / \mathrm{dm}^{3}\right]$ [27]

\begin{tabular}{|c|c|c|}
\hline Metal & IDL & IQL \\
\hline $\mathrm{Mn}$ & 0.0016 & 0.020 \\
\hline $\mathrm{Fe}$ & 0.0043 & 0.050 \\
\hline $\mathrm{Ni}$ & 0.0043 & 0.050 \\
\hline $\mathrm{Cu}$ & 0.0045 & 0.033 \\
\hline $\mathrm{Zn}$ & 0.0033 & 0.010 \\
\hline $\mathrm{Cd}$ & 0.0028 & 0.013 \\
\hline $\mathrm{Pb}$ & 0.0130 & 0.070 \\
\hline
\end{tabular}

In Table 2, concentrations of heavy metals in certified reference materials BCR-482 lichen, produced at the Institute for Reference Materials and Measurements, Belgium, are shown. 
Comparison of measured and certified concentrations in BCR-482 lichen

\begin{tabular}{|c|c|c|c|c|}
\hline \multirow{2}{*}{ Metal } & \multicolumn{2}{|c|}{ BCR-482 lichen } & \multicolumn{2}{c|}{ AAS } \\
\cline { 2 - 5 } & Concentration & Uncertainty & Average & \pm SD $^{*}$ \\
\cline { 2 - 5 } & \multicolumn{2}{|c|}{ [mg/kg d.m.] } & 31.70 & 0.68 \\
\hline $\mathrm{Mn}$ & 33.0 & 0.50 & n.d. & n.d. \\
\hline $\mathrm{Fe}$ & 804 & 160 & 2.16 & 0.32 \\
\hline $\mathrm{Ni}$ & 2.47 & 0.07 & 6.63 & 0.17 \\
\hline $\mathrm{Cu}$ & 7.03 & 0.19 & 95.1 & 2.30 \\
\hline $\mathrm{Zn}$ & 101 & 2.20 & 0.53 & 0.03 \\
\hline $\mathrm{Cd}$ & 0.56 & 0.02 & 38.2 & 1.00 \\
\hline $\mathrm{Pb}$ & 40.9 & 1.40 & & \\
\hline
\end{tabular}

* - standard deviation, ${ }^{* *}$ - relative difference between the measured $\left(c_{z}\right)$ and certified $\left(c_{c}\right)$ concentration $100 \% \cdot\left(c_{z}-c_{c}\right) / c_{c}$, n.d. - not determined

The $R A F$ - Relative Accumulation Factors was used to determine increases of concentrations of the analytes in the exposed mosses samples, as defined in [28]:

$$
R A F=\frac{C_{i, 1}-C_{i, 0}}{C_{i, 0}}
$$

where: $C_{i, 1}$ - concentration of an analyte after exposure period [mg/kg d.m.], $C_{i, 0}$ - concentration of an analyte before exposure period [mg/kg d.m.].

\section{Results and discussion}

Table 3 presents the results of heavy metal concentrations accumulated in moss, honey and bee samples.

Table 3

Heavy metals concentrations determined in moss, honey and bee samples

\begin{tabular}{|c|c|c|c|c|c|c|c|c|}
\hline \multirow{2}{*}{ Sampling sites } & \multirow{2}{*}{ Samples } & \multicolumn{7}{|c|}{ Concentration [mg/kg d.m.] } \\
\cline { 3 - 8 } & & Mn & Fe & Ni & Cu & Zn & Cd & Pb \\
\hline & M1 & 309 & 768 & 3.97 & 9.43 & 37.2 & $<0.81$ & $<4.38$ \\
A1 - Rogow & M2 & 308 & 699 & 3.29 & 10.1 & 36.9 & $<0.81$ & $<4.38$ \\
Opolski & M3 & 321 & 766 & $<3.13$ & 9.83 & 43.6 & $<0.81$ & $<4.38$ \\
& H & 5.22 & 18.7 & $<3.13$ & 1.39 & 10.0 & $<0.81$ & $<4.38$ \\
& HB & 149 & 118 & $<3.13$ & 18.4 & 120 & $<0.81$ & $<4.38$ \\
\hline & M1 & 263 & 750 & $<3.13$ & 8.26 & 37.3 & $<0.81$ & $<4.38$ \\
& M2 & 339 & 779 & $<3.13$ & 9.88 & 38.2 & $<0.81$ & $<4.38$ \\
A2 - Ligota & M3 & - & - & - & - & - & - & - \\
& H & 4.01 & 20.3 & $<3.13$ & 0.86 & 10.0 & $<0.81$ & $<4.38$ \\
& HB & 48.9 & 118 & $<3.13$ & 12.0 & 51.8 & $<0.81$ & $<4.38$ \\
\hline & M1 & 356 & 841 & 8.45 & 10.7 & 40.8 & $<0.81$ & $<4.38$ \\
& M2 & 335 & 667 & 5.60 & 9.41 & 36.2 & $<0.81$ & $<4.38$ \\
A3 - Mechnica & M3 & 5.22 & 727 & $<3.13$ & 8.99 & 40.4 & $<0.81$ & $<4.38$ \\
& H & 5.12 & 25.5 & $<3.13$ & 1.25 & 10.0 & $<0.81$ & $<4.38$ \\
& HB & 62.8 & 160 & $<3.13$ & 14.1 & 72.4 & $<0.81$ & $<4.38$ \\
\hline
\end{tabular}

A1 - apiary; M1 - moss samples; H - honey samples; HB - honeybee samples

Tables 4 and 5 present own research results compared with the data from literature. 
Heavy metals concentrations determined in honey samples in comparison to the data from literature

\begin{tabular}{|c|c|c|c|c|c|c|c|}
\hline $\begin{array}{c}\text { Analytes } \\
{\left[\mathbf{m g ~ k g}^{-1}\right]}\end{array}$ & $\begin{array}{c}\text { Current } \\
\text { study }\end{array}$ & {$[\mathbf{2 4}]$} & {$[\mathbf{1 5 ]}$} & {$[\mathbf{2 0 ]}$} & {$[\mathbf{2 9}]$} & {$[\mathbf{3 0 ]}[\mathbf{p p m}]$} & {$[\mathbf{4 ]}]$} \\
\hline $\mathbf{M n}$ & $4.01-5.22$ & $0.187 \pm 0.18$ & $\begin{array}{c}0.022439- \\
0.22762\end{array}$ & n.a. & n.a. & $0.044-6.31$ & $0.079-2.428$ \\
\hline $\mathbf{F e}$ & $18.7-25.5$ & $2.85 \pm 0.5$ & $\begin{array}{c}0.950132- \\
3.240654\end{array}$ & $162.31 \pm 49.21$ & $0.29-0.92$ & $10.49-80.38$ & $\begin{array}{c}<0.012- \\
10.054\end{array}$ \\
\hline $\mathbf{N i}$ & $<3.13$ & $0.26 \pm 0.2$ & $\begin{array}{c}0.011109- \\
0.067599\end{array}$ & n.a. & n.a. & $0.664 ; 7.64$ & $\begin{array}{c}<0.010- \\
0.538\end{array}$ \\
\hline $\mathbf{C u}$ & $0.86-1.39$ & $0.15 \pm 0.1$ & $\begin{array}{c}0.011461- \\
0.096664\end{array}$ & $1.96 \pm 0.94$ & $0.09-0.18$ & $10.73-75.5$ & $\begin{array}{c}<0.015- \\
1.781\end{array}$ \\
\hline $\mathbf{Z n}$ & 10.0 & $0.48 \pm 0.3$ & $\begin{array}{c}0.129515- \\
1.500897\end{array}$ & $43.88 \pm 46.58$ & $0.18-1.38$ & $0.336-1.48$ & $\begin{array}{c}<0.002- \\
4.346\end{array}$ \\
\hline $\mathbf{C d}$ & $<0.81$ & $0.0002 \pm 0.0$ & $\begin{array}{c}0.002302- \\
0.013221\end{array}$ & $0.35 \pm 0.38$ & $<0.02$ & n.d & $\begin{array}{c}<0.002- \\
0.009\end{array}$ \\
\hline $\mathbf{P b}$ & $<4.38$ & $0.04 \pm 0.09$ & $\begin{array}{c}0.00408- \\
0.114437\end{array}$ & $0.36 \pm 0.39$ & $<0.1$ & n.a. & $\begin{array}{c}<0.003- \\
0.107\end{array}$ \\
\hline
\end{tabular}

n.d. - not detected, n.a. - not analysed

Table 5

Heavy metals concentrations determined in honeybee samples in comparison to the data from literature

\begin{tabular}{|c|c|c|c|c|c|c|c|}
\hline $\begin{array}{c}\text { Analytes } \\
{\left[\mathbf{m g ~ k g}^{-1}\right]}\end{array}$ & $\begin{array}{c}\text { Current } \\
\text { study }\end{array}$ & {$[\mathbf{3}]$} & {$[\mathbf{6}]$} & {$[\mathbf{1 0}]$} & {$[\mathbf{3 1}]$} & {$[\mathbf{3 2}]$} & {$[\mathbf{3 3}]$} \\
\hline $\mathbf{M n}$ & $48.9-149$ & n.a & $40.5 \pm 13.08$ & $34-90$ & $20.69-50.80$ & $21-78$ & 41 \\
\hline $\mathbf{F e}$ & $118-160$ & n.a. & $177.2 \pm 54.20$ & $101-421$ & n.a. & $77-227$ & 130 \\
\hline $\mathbf{N i}$ & $<3.13$ & $\begin{array}{c}0.425 \pm 0.032 ; \\
0.358 \pm 0.037\end{array}$ & n.a. & $0.25-2.16$ & $0.19-0.47$ & $0.12-1.88$ & 0.48 \\
\hline $\mathbf{C u}$ & $12.0-18.4$ & $\begin{array}{c}17.93 \pm 0.98 ; \\
12.82 \pm 0.92\end{array}$ & $19.4 \pm 6.01$ & $11.8-29.2$ & $11.65-19.77$ & $11.8-29.2$ & 21.6 \\
\hline $\mathbf{Z n}$ & $51.8-120$ & $\begin{array}{c}58.11 \pm 4.61 ; \\
45.92 \pm 3.64\end{array}$ & $67.9 \pm 11.02$ & $65-156$ & $61.14-100.64$ & $59-179$ & 103 \\
\hline $\mathbf{C d}$ & $<0.81$ & $\begin{array}{c}0.024 \pm 0.002 ; \\
0.052 \pm 0.006\end{array}$ & n.a. & $0.046-0.33$ & $0.05-0.75$ & $\begin{array}{c}0.03- \\
0.260\end{array}$ & 0.14 \\
\hline $\mathbf{P b}$ & $<4.38$ & $\begin{array}{c}0.113 \pm 0.014 ; \\
0.127 \pm 0.017\end{array}$ & n.a. & $<$ DL-0.97 & $0.19-1.67$ & n.a. & 0.65 \\
\hline
\end{tabular}

n.d. - not detected, n.a. - not analysed, DL - Detection Limit

Figure 2 presents values of relative accumulation factor $R A F$, together with statistical parameters determined for the moss samples exposed in apiaries.

Based on the data presented in Table 3 it should be stated that for all three areas it was not possible to determine cadmium and lead - they were below the limit of quantification of the applied analytical F-AAS method. Additionally, one of the bags in apiary A2 was lost during the process, which reduced the number of results obtained for this measuring point. It should be noted that the samples from A1 area (in the vicinity of A4 motorway) contained higher concentrations in the case of bees than those from other locations - this could be observed for zinc or manganese. Copper concentration in bees in this location is the highest, compared to others. This could be influenced by the location of the measuring point - nearby the motorway. Other researchers also confirm that accumulation of heavy metals is related to the environment in which apiaries are located (in this case - urbanised areas). The authors enumerate such sources of analytes as the influence of industry or motor vehicles traffic on pollution of honeybees [6]. The studies carried out in urbanised areas 
provide data on pollution levels but also allow for assessing the possibility of using bees in long-term monitoring of anthropogenic changes and their use as the source of information about the changing environment conditions [21].

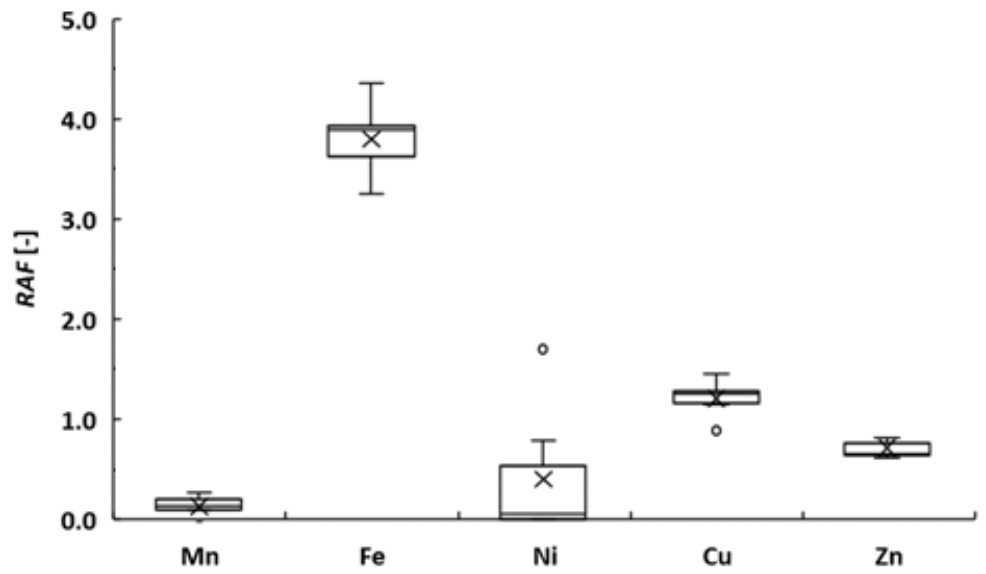

Fig. 2. $R A F$ values determined for the moss samples; (x) average, $(-)$ median, $\left({ }^{\circ}\right)$ outlier

The analysis of the results presented in Table 3 shows that there are no statistically relevant differences between heavy metals concentrations determined in the mosses exposed in three apiaries. The content of analytes in mosses was on a similar level for the three areas. According to the information obtained thanks to this biomonitor, the environment pollution level is similar for the studied areas. These results are confirmed also by Figure 2, which shows small increases of analytes concentrations. The mosses used in exposition were collected from the areas with high levels of heavy metals pollution [34].

The results of heavy metals content in honey were compared with the data from literature (Table 4). Concentrations of heavy metals accumulated in the honey used in the research were lower than the results presented in the quoted literature references. The limit of quantification of the used equipment is relevant in the case of such elements as cadmium or lead. The use of equipment with the appropriate low limit of quantification guarantees the possibility to determine even trace quantities of a given element [19]. In most cases, the maximum limit for lead was not exceeded $(0.1 \mathrm{mg} / \mathrm{kg})$ [35]. Some studies indicate that heavy metals pollution of honey in urban environment is unlikely, if all beekeeping good practices are followed [4]. Others demonstrate that in spite of certain heavy metals content (micropollution), honey is fit for human consumption [30].

Literature sources frequently describe studies, which refer to the results of heavy metals content in bees and honey. The research carried out in Saudi Arabia did not determine concentrations of $\mathrm{Cd}, \mathrm{Cr}, \mathrm{Ni}$ and $\mathrm{Pb}$ (the results were below the limit of quantification of the applied analytical method) in bee samples, interpreting it as the lack of pollution in the study area. It was emphasised that, in order to maintain this situation, standardisation and implementation of the appropriate beekeeping techniques are required [18]. It was indicated that the simultaneous use of honey and bees is more effective in environment monitoring than the use of honey only. In the research carried out in the vicinity of the power plant, concentration of cadmium was below limit of quantification, as 
in our samples [17]. Other studies indicate the possibility of the use of bees and honey as effective bioindicators in assessment of environment pollution. Nevertheless, the content of heavy metals below limit of quantification in honey may be caused by the fact that bees, by accumulating toxic metals, form a natural, biological barrier, which protects honey from pollution by analytes [36].

\section{Conclusion}

Biomonitoring studies carried out in the Opole Province in three apiaries allowed to assess heavy metals pollution level of the atmospheric aerosol in which the bee hives, bees in these hives and honey produced by the bees were located.

Out of the three biosorbents, the lowest heavy metals concentrations were accumulated in honey. Monitoring with the exclusive use of honey only may be an ineffective tool in assessing environment pollution level. The honey is fir for human consumption due to low or below limit of quantification concentrations of toxic metals.

Mosses showed similar heavy metals concentrations in all three areas. The increases versus the samples prior to exposition are low, which indicates relatively low pollution of the studied area with analytes.

Bees proved to be the most sensitive biomonitor. The accumulated most pollution and some of them correlated with the apiaries location area (apiary 1 nearby the motorway). The possibility of including honey bees in the air monitoring systems should be considered. This is supported not only by their characteristics of accumulating analytes but also economically justified cost of the material availability [2]. Own studies and literature indicate that bees are a good bioindicator of environment heavy metals pollution level [37]. They offer the possibility to analyse and describe changes in toxic metals concentrations in time or define sources of such pollution [33], as well as mosses [38].

\section{References}

[1] Gutiérrez M, Molero R, Gaju M, van der Steen J, Porrini C, Ruiz JA. Assessment of heavy metal pollution in Córdoba (Spain) by biomonitoring foraging honeybee. Environ Monit Assess. 2015;187:1-15. DOI: 10.1007/s10661-015-4877-8.

[2] Asif N, Malik M. A review of on environmental pollution bioindicators. Pollution. 2018;4(1):111-18. DOI: 10.22059/poll.2017.237440.296.

[3] Giglio A, Ammendola A, Battistella S, Naccarato A, Pallavicini A, Simeon E, et al. Apis mellifera ligustica, Spinola 1806 as bioindicator for detecting environmental contamination: a preliminary study of heavy metal pollution in Trieste, Italy. Environ Sci Pollut Res. 2017;24:659-65. DOI: 10.1007/s11356-016-7862-z.

[4] Jovetić MS, Redžepović AS, Nedić NM, Vojt D, Đurđić SZ, Brčeski ID, et al. Urban honey - The aspects of its safety. Arh Hig Rada Toksikol. 2018;69(3):264-74. DOI: 10.2478/aiht-2018-69-3126.

[5] Rncira MH, Araua SJ, Ucchib RZ, Artha FGB. On the origin and properties of scent marks deposited at the food source by a stingless bee, Melipona seminigra. Apidologie 2004;35(1):3-13. DOI: 10.1051/apido:2003069.

[6] Skorbiłowicz E, Skorbiłowicz M, Ciesluk I. Bees as bioindicators of environmental pollution with metals in an urban area. J Ecol Eng. 2018;19(3):229-34. DOI: 10.12911/22998993/85738.

[7] Nisbet C, Güler A, Biyik S. Effects of different environmental conditions on the cognitive function of honeybee (Apis mellifera L.) and mineral content of honey. Ankara Univ Vet Fak.Derg. 2019;66:95-101. Available from: http://dergiler.ankara.edu.tr/dergiler/11/2302/23957.pdf.

[8] Di N, Hladun KR, Zhang K, Liu TX, Trumble JT. Laboratory bioassays on the impact of cadmium, copper and lead on the development and survival of honeybee (Apis mellifera L.) larvae and foragers. Chemosphere 2016;152:530-38. DOI: 10.1016/j.chemosphere.2016.03.033. 
[9] Ruschioni S, Riolo P, Minuz RL, Stefano M, Cannella M, Porrini C, et al. Biomonitoring with honeybees of heavy metals and pesticides in nature reserves of the Marche region (Italy). Biol Trace Elem Res. 2013;154(2):226-33. DOI: 10.1007/s12011-013-9732-6.

[10] Zarić NM, Ilijević K, Stanisavljević L, Gržetić I. Metal concentrations around thermal power plants, rural and urban areas using honeybees (Apis mellifera L.) as bioindicators. Int J Environ Sci Technol. 2016;13(2):413-22. DOI: 10.1007/s13762-015-0895-x.

[11] Kocot J, Kiełczykowska M, Luchowska-Kocot D, Kurzepa J, Musik I. Antioxidant potential of propolis, bee pollen, and royal jelly: Possible medical application. Oxid Me Cell Longev. 2018;2018:7074209. DOI: $0.1155 / 2018 / 7074209$.

[12] Nascimento AMCB, Luz Jr GE. Bee pollen properties: uses and potential pharmacological applications a review. J Anal Pharm Res. 2018;7(5):513-15. DOI: 10.15406/japlr.2018.07.0027.

[13] Li F, Guo S, Zhang S, Peng S, Cao W, Ho CT, et al. Bioactive constituents of F. esculentum bee pollen and quantitative analysis of samples collected from seven areas by HPLC. Molecules. 2019;24(15):E2705. DOI: 10.3390/molecules24152705.

[14] Denisow B, Denisow-Pietrzyk M. Biological and therapeutic properties of bee pollen: a review. J Sci Food Agric. 2016;96(13):4303-09. DOI: 10.1002/jsfa.7729.

[15] Tiwari P, Naithani P, Tiwari JK. determination of heavy metals in honey samples from sub-montane and montane zones of Garhwal Himalaya (India). World J Pharm Pharmac Sci. 2016;5(7):812-19. DOI: 10.20959/wjpps20167-6903.

[16] Sager M. The honey as a bioindicator of the environment. Ecol Chem Eng S. 2017;24(4):583-94. DOI: 10.1515/eces-2017-0038.

[17] Silici S, Uluozlu OD, Tuzen M, Soylak M. Honeybees and honey as monitors for heavy metal contamination near thermal power plants in Mugla, Turkey. Toxicol Ind Health. 2016;32(3):507-16. DOI: $10.1177 / 0748233713503393$.

[18] Aljedani DM. Determination of some heavy metals and elements in honeybee and honey samples from Saudi Arabia. Entomol Appl Sci Lett. 2017;4(3):1-11. Available from: https://easletters.com/index.php?journal= journal\&page $=$ article\&op=view \&path $\% 5 \mathrm{~B} \% 5 \mathrm{D}=194$.

[19] Galbiati F, Panseri S, Labella G, Giorgi A, Pavlovic R, Bonacci S, et al. Determination of pesticides and persistent organic pollutants in honey by accelerated solvent extraction and GC-MS/MS. Available from: https://assets.thermofisher.com/TFS-Assets/CMD/Application-Notes/CAN-125-GC-MS-Pollutants-HoneyCAN72132-EN.pdf.

[20] Moniruzzaman M, Chowdhury MAZ, Rahman MA, Sulaiman SA, Gan SH. Determination of mineral, trace element, and pesticide levels in honey samples originating from different regions of Malaysia compared to Manuka honey. Biomed Res Int. 2014;2014:359890. DOI: 10.1155/2014/359890.

[21] Perugini M, Manera M, Grotta L, Abete MC, Tarasco R, Amorena M. Heavy metal ( $\mathrm{Hg}, \mathrm{Cr}, \mathrm{Cd}$, and Pb) contamination in urban areas and wildlife reserves: Honeybees as bioindicators. Biol Trace Elem Res. 2011;140(2):170-76. DOI: 10.1007/s12011-010-8688-Z.

[22] Herrero-Latorre C, Barciela-García J, García-Martín S, Peña-Crecente RM. The use of honeybees and honey as environmental bioindicators for metals and radionuclides: A review. Environ Rev. 2017;25(4):463-80. DOI: 10.1139/er-2017-0029.

[23] Bogdanov S, Haldimann M, Luginbühl W, Gallmann P. Minerals in honey: environmental, geographical and botanical aspects. J Apicult Res. 2007;46(4):269-75. DOI: 10.1080/00218839.2007.11101407.

[24] Pehlivan T, Gül A. Determination of heavy metals contents of some monofloral honey produced in Turkey. J Appl Pharm Sci. 2015;5(8):42-5. DOI: 10.7324/JAPS.2015.50807.

[25] Greco Miani A, Quinto M. Can lead in honey be dangerous for children health? EC Nutr. 2017;12.3:117-19. Available from: https://www.ecronicon.com/ecnu/pdf/ECNU-12-00410.pdf.

[26] Rajfur M, Świsłowski P, Nowainski F, Śmiechowicz B. Mosses as biomonitor of air pollution with analytes originating from tobacco smoke. Chem Didact Ecol Metrol. 2018;23(1-2):127-36. DOI: 10.1515/cdem-2018-0008.

[27] Thermo Fisher Scientific Inc. iCE 3000 Series AA Spectrometers Operator's Manual. 2011. Available from: http://photos.labwrench.com/equipmentManuals/9291-6306.pdf.

[28] Zinicovscaia I, Urošević MA, Vergel K, Vieru E, Frontasyeva MV, Povar I, et al. Active moss biomonitoring of trace elements air pollution in Chisinau, Republic of Moldova. Ecol Chem Eng S. 2018;25(3):361-72. DOI: 10.1515/eces-2018-0024.

[29] Mujić I, Alibabić V, Jokić S, Galijašević E, Jukić D, Šekulja D, et al. Determination of pesticides, heavy metals, radioactive substances, and antibiotic residues in honey. Polish J Environ Stud. 2011;20(3):719-24. Available from: https://pdfs.semanticscholar.org/d625/07e0b974ec8bc8f84a162f02d95a755a11e6.pdf. 
[30] Ciobanu O, Rădulescu H. Monitoring of heavy metals residues in honey. Res J Agric Sci. 2016;48(3):9-13. Available from: http://www.rjas.ro/download/paper_version.paper_file. 92d3e0fe707baa80.63696f62616e75206f616e612e706466.pdf.

[31] Van Der Steen JJM, De Kraker J, Grotenhuis T. Spatial and temporal variation of metal concentrations in adult honeybees (Apis mellifera L.). Environ Monit Assess. 2012;184(7):4119-26. DOI: 10.1007/s10661-011-2248-7.

[32] Zarić NM, Ilijević K, Stanisavljević L, Gržetić I. Use of honeybees (Apis mellifera L.) as bioindicators of spatial variations and origin determination of metal pollution in Serbia. $J$ Serbian Chem Soc. 2018;83(6):773-84. DOI: 10.2298/JSC171110018Z.

[33] Zarić NM, Ilijević K, Stanisavljević L, Gržetić I. Use of honeybees (Apis mellifera L.) as bioindicators for assessment and source appointment of metal pollution. Environ Sci Pollut Res. 2017;24(33):25828-38. DOI: 10.1007/s11356-017-0196-7.

[34] Arndt J, Planer-Friedrich B. Moss bag monitoring as screening technique to estimate the relevance of methylated arsine emission. Sci Total Environ. 2018;610-611:1590-94. DOI: 10.1016/j.scitotenv.2017.06.123.

[35] Commission Regulation (EU) 2015/1005 of 25 June 2015 amending Regulation (EC) No 1881/2006 as regards maximum levels of lead in certain foodstuffs. Available from: https://op.europa.eu/en/publicationdetail/-/publication/f7405b97-1bc7-11e5-a342-01aa75ed71a1/language-en.

[36] Dżugan M, Wesołowska M, Zaguła G, Kaczmarski M, Czernicka M, Puchalski C. Honeybees (Apis mellifera) as a biological barrier for contamination of honey by environmental toxic metals. Environ Monit Assess. 2018;190(2):101. DOI: 10.1007/s10661-018-6474-0.

[37] Davodpour R, Sobhanardakani S, Cheraghi M, Abdi N, Lorestani B. Honeybees (Apis mellifera L.) as a potential bioindicator for detection of toxic and essential elements in the environment (case study: Markazi Province, Iran). Arch Environ Contam Toxicol. 2019;77(3):344-58. DOI: 10.1007/s00244-019-00634-9.

[38] Aleksiayenak Y, Frontasyeva M. A ten-year biomonitoring study of atmospheric deposition of trace elements at the territory of the Republic of Belarus. Ecol Chem Eng S. 2019;26(3):455-64. DOI: 10.1515/eces-2019-0034. 